\title{
Multilingual dynamics among Portuguese-based migrant contexts in Europe
}

\author{
Maria Clara Keating ${ }^{\mathrm{a}, *}$, Olga Solovova ${ }^{\mathrm{b}, 1}$ \\ a School of Arts and Humanities, Faculdade de Letras da Universidade de Coimbra, Largo da Porta Férrea, 3004-530 Coimbra, Portugal \\ ${ }^{\mathrm{b}}$ Centre for Social Studies, Colégio de S. Jerónimo, Apartado 3087, 3001-401 Coimbra, Portugal
}

\section{A R T I C L E I N F O}

\section{Article history:}

Received 24 March 2009

Received in revised form 16 June 2010

Accepted 21 June 2010

Available online 29 September 2010

\section{Keywords:}

Multilingual literacies

Re-scaling

Migration

Portuguese

Russian

Ukrainian

Polycentricity

Polycentricity and Space

\begin{abstract}
A B S T R A C T
This paper explores insights and understandings of multilingual dynamics within European-based migrant contexts where Portuguese plays a role. The intermediate position of Portuguese migration in Europe (simultaneously host and sending country) gives Portuguese a bipolar sociolinguistic status at the European scale, both as a 'dominant' and 'non-dominant' language, useful to use as an analytical springboard. Drawing on linguistic ethnographic work developed in two sites - Portuguese migrant women in London and Eastern European migrant children in Portugal - this paper discusses the tools used to (a) describe the informal emerging and creative multilingual use happening in local configurations of speakers, linguistic ideologies, artifacts, histories and institutions, and (b) explain how this creativity is re-scaled into dominant discourses situated in momentary yet simultaneously long-term historical sociolinguistic configurations, differently narrated by the multiple actors involved. A combined focus on personal trajectories and 'history in person', discursive dynamics of recontextualisation and rescaling and an understanding of the power dynamics in intersubjective spaces helps develop the idea of polycentric speaking positions, affected by local creativities and constraints happening in conflicting historically configured hybrid spaces of verbal interaction.
\end{abstract}

(c) 2010 Elsevier B.V. All rights reserved.

\section{Introduction}

Migration has been part of the structural character of Portuguese society since the fifteenth century. Even though migration fluxes were oriented mainly towards non-European areas, with massive migration waves to Brazil and the United States of America in the 19th century, they became redirected to a number of northern European countries by the mid 20th century (Baganha, 1988).

At the beginning of the 21st century, Portugal finds itself in a position that still allows the historical choice of emigrating but articulates it with hosting refugees and migrants, including from geographical areas having no apparent historical links with Portuguese colonisation. Portugal's entry in the Common Market in 1986 was a crucial factor in new Portuguese migrant configurations in Europe. European citizenship apparently multiplied the possibilities of success for Portuguese citizens. However, this disguises the established socio-historical and material options to emigrate, at hand for Portuguese nationals during economic crisis and unemployment. This is illustrated by the existence of pockets of Portuguese workforce throughout

\footnotetext{
* Corresponding author. Tel.: +351239 859900; fax: +351239836733.

E-mail addresses: clarakeating@ces.uc.pt, kleating@gmail.com (M.C. Keating), olga@ces.uc.pt (O. Solovova).

${ }^{1}$ Tel.: +351 239855 570; fax: +351239855 589.
} 
Northern Europe - Britain, the Netherlands, Spain, among others - in a way that still makes it possible to talk about a 'migrant condition', thus bringing to light the social and economic inequalities between the North and the South of Europe.

In a paper entitled "A cada sul o seu norte" ("To each South its North"), Baganha acknowledges the bipolar nature of migrant fluxes linking Portugal and Europe (Baganha, 2001). Due to its intermediate position in the global system, Portugal is considered by Baganha to play the role of a hub importing and exporting labour force for overlapping institutional structures operating in the European context. This complexity of institutional structures at the European scale makes it hard to arrive at unified migration policies for the European Union. The hub metaphor helps understand the influx and outflux of people (and of languages they speak ${ }^{2}$ ), typical of the contemporary profile of migration in Portugal (Baganha, 2001:147).

This complex landscape needs to be explored, not only in social and sociological (cf. Santos, 1995, 2001; Baganha, 2001) but also in discursive and sociolinguistic terms. It opens the possibility to analyse the use of Portuguese in Europe from at least two positions, thus acknowledging the existence of overlapping institutional structures acting simultaneously: one, where Portuguese is used as a language of agency, in subordinate and minority contexts attempting to dialogue, align, resist and/or propose alternative interpretations to dominant states of affairs; two, where Portuguese is seen as a language of structure, used in dominant contexts and maintaining its national and Portuguese-speaking diasporic space strongly influenced by monolingual language practice and ideology. Hence, this paper draws from ethnographic work developed in two different sites in Europe where European Portuguese displayed this ambivalent status: a long-term study on the lived experiences with language and literacy of Portuguese migrant adult women in London (undertaken by Clara Keating) and an ongoing study of a similar nature within a group of Eastern European migrant children in central Portugal (by Olga Solovova).

In her study of language and literacy among Portuguese women in London, Keating focused on the dynamic routes through literacy of the individual women involved, as these routes were situated both in their personal experiences and in the subjectivities opened up by the hybrid literacy practices that they had to deal with in their process of relocation from Portugal to London and across London over a number of years. Activity theory (Engeström, 1999), as well as a focus both on the life cycles of individual women and on discourse in situated events and encounters where they participated, helped her focus on the "person in the doing", as being positioned by overlapping historically configured constraints available for "the Portuguese migrant" and/or "the European citizen" in the multilingual urban context of London (cf. Keating, 2005, 2009)

The ongoing study among Eastern European migrants in central Portugal stems from ethnographic study on the bilingual and biliterate experiences of a group of primary school children of Eastern European migrant origin. Based on an informal school of Russian language and culture, Solovova accompanied six children of various nationalities for a period of 18 months as they were gradually becoming literate in Russian. The study described the processes through which these children developed Russian literacy learning and identified factors that were influential in these processes. Adult participants in the project were shown to invest their own literacy values in the children's learning (cf. Norton, 2000), by direct teaching as well as by indirect transmission of experiences, beliefs and attitudes. Peers also turned out to be highly influential in the learners' literacy development and uses of literacy. With gradual awareness of the similarities and differences between the Russian and Portuguese writing systems, learners negotiated their biliterate identities by separating or combining the means of representation available to them through the two systems. This creative process implied children's assessment of the contexts - personal, immediate and broader contexts - in which problem-solving and decision-making was situated (Solovova, 2005).

The paper draws from data collected in the two sites described above in order to explore the uses of language and literacy displayed by individual participation in events. Drawing from insights on "history in person" (cf. Holland and Lave, 2001), we focus on the person in the doing as it manifests polycentric speaking positions, i.e., a multitude of possible utterances situated in a particular meeting of histories from which the person acts and makes linguistic decisions in a creative way, as she solves tensions and/or assesses possibilities of future action. ${ }^{3}$ The next section will focus on how, in our data, the creation of such position - or of a multitude of possible positions - was envisaged. It derived from the triangulation of data from multiple sources - interviews, participant observation, analysis of verbal interactions and analysis of literacy artifacts - as well as from the longitudinal approach in both research contexts.

\section{Trajectories, conditions and creativities}

To articulate past and present individual participation in events in the same analysis, we have focused on three aspects of the person's language and literacy activity: one, the person's lived trajectories of language and literacy, as well as those of

\footnotetext{
${ }^{2}$ For the first time in its history, Portuguese society has to deal with new sociolinguistic configurations that emerge as a consequence of global migration flows (Baganha, 2005). Sociolinguistic research on language use in multilingual settings is now intensifying (Mateus, 2002; Mateus et al., 2005; Dionízio, 2005; Ançã, 2007; Pereira, 2006) but shows that multilingual uses are being framed by strong monolingual ideologies of language and the nation-state. Sociolinguistic research on Portuguese as minority language in the UK in the 1990s was almost nonexistent, except for work developed out of the Language Minorities Project in the 1980s (Stubbs, 1985; Reid et al., 1985; Martin-Jones and Santarrita, 1990). Since then, there has been growing interest in the Portuguese community in the UK, illustrated by the work developed in social psychology, multilingual education, and sociolinguistics, both in Portugal and in the UK (cf. Abreu and Elbers, 2005; Abreu and Lambert, 2003; Barradas, 2000, 2010a,b; Cardoso, 2004; Keating, 2001, 2005, among others). The growing population of Portuguese speaking African, Brazilian and Timorese origin in London, however, contributes significantly to a broader picture on the uses of Portuguese in London, in urgent need of further systematic research.

${ }^{3}$ Polycentricity has been used by different authors to describe differentiated perceptions and regimes of multilingualism as acceptable sets of uses and resources instigated by different places, Blommaert et al. (2005a,b). Cf. also Zentella (2007) on the polycentric space in the Mexican border and the existence of distinct bilingual regimes.
} 
other meaningful actors (human and non-human) operating in the person's meaning making process; two, the person's discursive negotiation in the course of participation in events, i.e., the work of recognition of language activity as shared social and discursive doings in communities of practice and discourse, i.e., relevant language and literacy practices; three, the ways in which configurations of social context and language practice - i.e., constraints situated in institutions and histories determined the person's assessment of future actions and eventual future aspirations for senses of self. Focusing on the discursive negotiations between the conditions of contexts and the creative potential of our speakers - and making an attempt to explain them in terms of trajectories and lived experiences with language and literacy - helped us understand in empirical ways the local multilingual distributions and how they were configured by contesting broader historical and ideological process.

In section 2.1, Keating focuses on two speakers, mother and child, by following their language and literacy trajectories in their home, community and schools. In section 2.2, by describing a different event with the same people, this time in their home, Keating then illustrates how a focus on individual speakers can be complemented with a focus on the intersubjective negotiations happening as two participants in the same event discursively assess the same activities as different ways of doing. This is further expanded in sections 2.3 and 2.4, as Solovova's focuses on an event drawn from her work with children of Eastern European migrants in Portugal, where she explores the ways in which different linguistic authorities were enacted in the production of a child's literacy artifact and how this could be seen as affecting this child's way of envisaging future possibilities of action.

\subsection{Trajectories of language and literacy: Dina and Sónia}

\subsubsection{Dina}

Dina's arrival to London in the 1970s fits into broader flows of Southern European migrants to Northern Europe in a particular historical period in Europe and her lived experiences with literacy have already been described elsewhere (Keating, 2009:237-238). Her early contacts with one politically active Portuguese association that networked both with movements of resistance to the Portuguese totalitarian regime in the diaspora and with workers movements and trade unionism acting in the London workplace context provided her with a multi-scaled informal and semi-formal learning space and with very useful resources and literacies that she deployed in her politically active working and community life throughout the years as part of her enduring struggle of being 'Portuguese in London' (cf. Holland and Lave, 2001). This meant that Dina was actively involved in literacy chores, as well as uses of texts, genres and styles that characterised the network of practices related to the management of her association as part of 'the worldwide community of Portuguese emigrants' (as these identities were constructed by official government discourses on Portuguese nationals abroad in the 1990s, the main aim of which was to keep the identity affinities with the 'mainland' alive and to secure 'emigrants' remittances for the overall impoverished budget of Portugal). This sense of prestige also affected her strong investment in the formal education for her children that she did not have access to in 1950s' Portugal. Her use of Portuguese was linked to her yearly summer visits to Portugal, RTP Internacional (Portuguese cable TV channel), Saturday afternoon association events, some reading materials that she brought from the association, her contacts with the Portuguese consulate, as well as a strong sense of value and prestige related to the traditional learning methods in which she herself had been socialized. In the early years of the research, Dina usually helped her youngest child Sónia with her homework "the way we did it in Portugal" (spelling, dictation, and handwritten copies of print texts, etc.) and reading out history books about the "fantastic Portuguese culture and history".

\subsubsection{Sónia}

Dina's youngest child Sónia was born in London. Clara Keating met her between the age of 6 and 10, when she divided her time between home, school, and the migrant association where she had most of her friends. Due to her parents' involvement in it, Sónia usually spent her weekends helping her mother prepare events and then waiting for her to clean up the community space. At an early age, Sónia usually spent her time with the Portuguese-speaking adults in the larger ballroom. At 10, Sónia joined other children in the adjacent room where they played games and listened to music, all of these activities being rooted in multilingual discourses and styles.

Sónia was an active reader and writer. Over the years, she shared with Clara her drawings and school homework, her interest in books, reading and writing materials (all kept neat and coloured), as well as her interest in cell phones, audio and digital tape recorders (and a computer that she longed to have). A lot of her reading and writing interests were linked to school and other school-related activities like visits to museums and other places of cultural interest.

At home mother and child usually spent time together by watching RTP Internacional and by reading whatever they happened to have at home, as, according to Dina, "most of their books in Portuguese were in Portugal". The mother made a clear distinction between what she considered her Portuguese books (those she had had in her home in Portugal) and other kinds - but also Portuguese - of print and literacy materials that could be found in their London home.

Even though the family knew about the existence of afterschool classes of Portuguese in London, these were given at a place very far from Sónia's home and school. Dina thus left the child on her own, certain that her daughter would learn the Portuguese language very quickly once she set her mind to it. Sónia would usually "read the Portuguese regional and national newspaper" bought in a Portuguese neighbourhood, opened her mother's correspondence related to the migrant association, used her books and magazines and had a peek at her older brother's papers. Usually, Sónia was left by herself around the 
house as she engaged in her "reading and writing things". Up until she was 10, Sónia maintained a continued interest in books, magazines, TV programmes on the history of Portugal, Britain and the Egyptians, which resonated her mother's attention to history as a way of maintaining her national pride in an English-dominant world. Later in the research, Sónia was about to start attending a complementary Portuguese school and was utterly excited about having been accepted by a prestigious private catholic school in London.

\subsection{O livro da Anita and The Big Book of Knowledge}

The event took place in Dina's household in the evening during one of the many research interviews "on uses of language and literacy" over the years. It followed Dina's comments on her daughter Sónia's reading and writing skills in Portuguese. To illustrate Sónia's interest, Dina encouraged her child to read a Portuguese book to the interviewer. The following is an excerpt from the researcher's fieldnotes:

"Sónia stood up, went to her room and brought two books with her - O livro da Anita and The Big Book of Knowledge placing them next to me on the sofa on top of the school material she had shown me before. She opened the first book on the first page and started to read slowly in a low voice. Her reading was engulfed by other noisy activities: the cable TV (RTP Internacional) was on quite loud, her father kept interrupting; Dina was making conversation and offering drinks. I concentrated on Sónia's slow and hesitant reading performance and helped her, with a teacher-like voice, when she stumbled on the word "equitação" (horse riding).

Sónia stopped trying. After a pause, I picked up a sentence on 'Arabic horses', read it slowly and started a conversation about Arabic horses. Her mother came in with the coffee and took over the conversation. The interaction then shifted into mother and child's, where the mother tried to help the child by making her join letters into syllables [ $b+a=b a]$, but the daughter did not respond. Dina commented on this by saying how little time she had to educate her child in Portuguese. Sónia kept on reading and after a while uttered distinctly a whole sentence on her own. I asked her "whether she got the meaning of what she had read". She met it with loose words, silence and laugh. All laughed. I switched to English. Sónia said something about Anita's book in English, put it aside, picked The Big Book of Knowledge, and started reading it quite fluently. I focused my attention on Sónia as her mother commented on how she did not read that badly in Portuguese, for someone who was "learning in another country, without any help from formal classes in Portuguese".

Sónia was now reading confidently her English book. During this time, Dina commented on the previous activity and started talking to her husband about something else, in Portuguese. Sónia remained oblivious to all the activity around her, immersed in her English reading. I reacted, in English, as she stumbled on the word "spectacular". I asked her in English what Roman fountains were. To this, Sónia answered in Portuguese, saying that they were fountains where the Romans used to fetch water. This turn-taking was commented by Dina as an instance of the outstanding complex skill that her daughter had, of translating English into Portuguese, "even in conversation". Dina then acknowledged that most of the times they "were not aware of the talking" in the household, and that Sónia stuck to English on most occasions. I shifted the topic to watching TV. I mentioned that in the previous year, Sónia and her mother used to watch the Portuguese cable TV together. Dina responded by recalling how Sónia used to learn new Portuguese words by watching a TV word contest. I asked the girl in English whether she preferred English or Portuguese TV, to which she answered that she preferred Portuguese soaps because they "had an end, whereas the English ones never ended". With this, Sónia took the floor in English and the conversation went on about Sónia's literacies. The conversation led to Sónia's interest on the Egyptians, and her mother also took an active part in the conversation in English. We were now fully in Sónia's field and the girl stood up to fetch another book about the Egyptians".

( $3^{\text {rd }}$ interview/G6/b/000 - 197; personal field notes)

Represented in Table 1 below, this event unfolded in a number of tensions associated to the discursive representations of bilingual literacy distribution in this household, differently envisaged by Dina and Sónia. We illustrate some of what we considered the most significant individual actions, sustained in a number of other discursive and conversational moves in need of further expansion.

The choice of literacy artifacts revealed distinct agendas for participants. When asked by her mother to fetch a Portuguese book, Sónia decided to bring two books - a Portuguese as well as an English one. O livro da Anita is a Portuguese classic series of short stories for children in an A4 hard cover format, whose pictures and stories have remained unchanged for the last 30 years. Pages were divided between the top half page by a picture depicting a 10-year-old girl - Anita - engaging in various activities (in this particular issue, Anita a Cavalo, Anita holds the reins of a horse) and a text in large print underneath. The Big Book of Knowledge was at the time a new English children's book published by Dorling Kindersley, with an appealing presentation of non-fiction facts about history and science, where pictures and text intermingled into various different nonlinear orientations on the page. Anita a Cavalo was a book offered to Sónia by her mother, so that she could practice her reading in Portuguese. The Big Book of Knowledge was picked up in London by Sónia herself, due to her interest in Romans and Egyptians that she had gained in school, from her schoolteacher and school visits to the British Museum.

Dina and Sónia also associated 'Portuguese' to different things and evaluated the same literacy activities as part of different practices. Dina voiced memories of her own traditional schooling experiences (e.g. using the method of combining 
Table 1

Dina and Sónia.

\begin{tabular}{|c|c|c|}
\hline Dina's actions & $\begin{array}{l}\text { Negotiations: performing } \\
\text { uses of languages at home }\end{array}$ & Sónia's actions \\
\hline $\begin{array}{l}\text { Displaying use of Portuguese in the household by } \\
\text { (a) Choice of material artifacts } \\
\text { (b) Voicing traditional schooling practices and } \\
\text { monolingual assessments of language activity } \\
\text { (c) Illustrating RTP International as means of } \\
\text { language maintenance }\end{array}$ & $\begin{array}{l}\text { Performing topic } \\
\text { On the use of } \\
\text { Portuguese at home }\end{array}$ & $\begin{array}{l}\text { Displaying use of Portuguese and English in the } \\
\text { household by } \\
\text { (a) Active choice of material artifacts in both languages } \\
\text { (b) Engaging in reading practices in both languages } \\
\text { and displaying fluency in English } \\
\text { (c) Assessing TV programmes in bilingual } \\
\text { distributions of genres, instead of language systems, } \\
\text { their use and their maintenance }\end{array}$ \\
\hline $\begin{array}{l}\text { Anita a Cavalo as instance of the use of Portuguese } \\
\text { in the household }\end{array}$ & $\begin{array}{l}\text { Performing } \\
\text { material artifacts }\end{array}$ & $\begin{array}{l}\text { Big Book of Knowledge as instance of Sónia's interests } \\
\text { (in spite of Anita) }\end{array}$ \\
\hline $\begin{array}{l}\text { Paying attention to Sónia by 'acting teacher’: } \\
\text { helping her join letters into syllables } \\
\text { "e-q+u+i = equi” }\end{array}$ & Anita a Cavalo & Stumbling in the word equitação(horse riding) \\
\hline $\begin{array}{l}\text { Dina laughs; monolingual assessments of Sonia's } \\
\text { performance in Portuguese }\end{array}$ & & $\begin{array}{l}\text { Mimicking in loud voice associations of sounds } \\
\text { to words in a sentence } \\
\text { Interviewer frames in terms of "comprehension". } \\
\text { Sónia laughs }\end{array}$ \\
\hline \multirow[t]{2}{*}{$\begin{array}{l}\text { Shifting attention away from the event and from } \\
\text { Sonia's performance in English }\end{array}$} & The Big Book of Knowledge & $\begin{array}{l}\text { Switching to English, picking up the Big Book } \\
\text { of Knowledge, reading fluently in English }\end{array}$ \\
\hline & $\begin{array}{l}\text { Performing languages } \\
\text { (language choice) }\end{array}$ & \\
\hline $\begin{array}{l}\text { Voicing traditional schooling practices; educated } \\
\text { styles in Portuguese for fellow national } \\
\text { interviewer }\end{array}$ & $\begin{array}{l}\text { Portuguese-based } \\
\text { interaction } \\
\text { Words: e.g. equitação } \\
\text { Reading activities in } \\
\text { Portuguese }\end{array}$ & $\begin{array}{l}\text { Stumbling in words; pauses and silences; } \\
\text { mimicking reading practices in Portuguese, laughs }\end{array}$ \\
\hline $\begin{array}{l}\text { Assessment of CS as Sónia's outstanding } \\
\text { translation skill }\end{array}$ & Code-switch & $\begin{array}{l}\text { Paraphrasing; "roman fountains é onde os romanos } \\
\text { vão buscar água" }\end{array}$ \\
\hline English-based interaction & English-based interaction & English-based interaction \\
\hline $\begin{array}{l}\text { Fluent use of English; stating opinions on TV } \\
\text { programmes as maintenance of Portuguese }\end{array}$ & & $\begin{array}{l}\text { Fluent use; stating personal opinions on TV } \\
\text { programmes as entertainment: assessing genres } \\
\text { independently of language }\end{array}$ \\
\hline
\end{tabular}

letters into syllables $-\mathrm{b}+\mathrm{a}=\mathrm{ba}$ ) and justified her daughter's performance with the little time she could spend on her child's education in Portuguese. She then appropriated other instances to illustrate the use of Portuguese, such as her daughter's code-switch as 'translation from English to Portuguese' and their shared practice of watching language contests on Portuguese cable TV. The analysis of Dina's literacy trajectories allowed us to associate her language maintenance to a sense of national prestige, embedded in official Portuguese-based discourses about being an emigrante. ${ }^{4}$ Within the broad frame of the research interviews, Dina was illustrating her family's use of Portuguese at home as an instance of "being Portuguese".

Sónia illustrated her own reading skills, independently of the language. By choosing the English book, not only did she reconfigure the reading activity, she also shared her personal interests in a particular number of topics and genres in both languages, thus not aligning to her mother's emphasis on Portuguese. When given space to perform in Portuguese, she kept awkward silences until she had the opportunity to actively perform in English. Her preference towards Portuguese soap operas was justified by the fact that they "had an end", as opposed to the English Neighbours or Home and Away. This preference had to do with genre rather than with the language. Sónia's bilingual distribution of language and literacy was thus moving away from the assessment imposed by her mother of clear boundaries between language systems (i.e., in Portuguese, in English).

Discursive tensions were negotiated throughout the event. The child did not perform as her mother had expected, which led to a recombination of meanings. First, 'use of Portuguese' was articulated as 'reading books', then further rearticulated as 'watching language contests on the Portuguese TV' and finally as 'watching Brazilian Portuguese soap operas'. By the end of the event, 'reading books' had been categorized as being performed in English rather than in Portuguese. The Anita was practically ignored; and Dina accommodated to Sónia and Clara in English, by joining in their English-based conversation about Sónia's interest in the Egyptians. This illustrated that literacy distribution within this household was deeply bilingual, and that the maintenance of Portuguese at home was associated not to the reading or other literacy activities considered prestigious by Dina, but to more informal TV genres broadcasted by the Portuguese cable TV. Dina's insistence on displaying

\footnotetext{
${ }^{4}$ Elsewhere, Keating has illustrated how Dina's sense of self was anchored in the national definition of the Portuguese emigrant ("o emigrante"), a strong traditional cultural representation of Portuguese migrants in Portugal, also opened up in various official, political, cultural and literary texts about Portuguese migration to Europe and the Americas (cf. Keating, 2001).
} 
the use of Portuguese at home was thus negotiated with her daughter's interests and reframed in terms of different genres and practices.

\subsection{Oleg, schooling, and decisions on spelling}

The dissolution of the USSR and the collapse of the Warsaw Bloc opened a new leaf in the geopolitical history of Europe, having triggered previously unseen global migration processes, such as Eastern European migration to Portugal. This migration is a fairly recent phenomenon, having its peak in 2001, when Ukrainian immigrants outnumbered the more traditional Cape-Verdean immigrant community.

The large influx into the country in the 2000s has spurred on research and lawmaking on migration, as the Portuguese state, academy and society in general tried to grasp the nature of the phenomenon. Formerly perceived as largely monolingual, the nation-state started to develop language policies that determined the status of both Portuguese and the newcomers' languages. Emerging from local voluntary initiatives, the attempts of formulating language policies have become increasingly centralized with the launch of various programmes of teaching Portuguese 'as non-native language' in professional and educational contexts. Students from 'non-Portuguese' linguistic backgrounds were placed in mainstream classrooms, being provided specific 'Portuguese as a non-native language' classes during mainstream classes on more language-based subjects, combined with some extracurricular support in Portuguese. The languages of immigrants were defined as 'cultural manifestations' and given local support accordingly (e.g. in museums, exhibitions, cultural festivals).

Eastern European immigrant social organisations, that appeared as early as in 2002, have also contributed in the local efforts towards creating language policies, since some of them established Portuguese classes for newcomers, as well as provided mother tongue classes for immigrant children.

The informal school for migrant children of Eastern European origin where Solovova's research is based had emerged as a parent initiative and started to function as a home school. Over the years it has gradually outgrown this space to become an informal school for children of different ages, nationalities and families from various social strata and migration histories. In order to gain visibility in the Portuguese society, it had to undergo a process of institutionalisation as an association of Eastern European immigrants. Contacts with representatives of local and national institutions in this process have resulted in re-negotiation of association's objectives and priorities, i.e. from learning/teaching context to a space of cultural promotion. The informal school thus exists as a space of agency within the constraints provided by the Portuguese state policies towards immigrants and their languages. On the other hand, it dwells on the interface of formal vs. informal schooling, monolingual vs. multilingual pedagogies, the Portuguese state dominant ideologies of languages and learning vs. alternative ideologies originating in parents' personal trajectories of socialisation in Russian, Ukrainian and Romanian languages and schooling in the different republics of the multilingual state of the USSR and post-Soviet states.

The following is an excerpt from Oleg's written homework produced for Solovova's Russian class at an Eastern European migrant community school, in Portugal. The artifact below represents a written response related to a text which was previously read in class. The text itself runs: "Vova was given a dictionary because he could not write [properly, without spelling mistakes]" (Figs. 1 and 2).

A closer look at the artifact makes it evident that another person was present at the time the boy was doing his homework, as some letters and words are written in a different handwriting. When Solovova took this piece of data to the boy's household, it turned out that it had been Oleg's mother who had helped him with this particular text. First the boy's mother provided letter models for Oleg to copy, then corrected two words (those written above the lines), and ended up helping him write the whole text. As a result, there were two versions of the sentence as the mother made him rewrite it due to too many 'mistakes'. Along with other words, she crossed out the Ukrainian word for "dictionary (словник- "slovnik", the circled word) which Oleg had used and placed above it the Russian counterpart (словарь- "slovar"”). Both the Russian and Ukrainan words

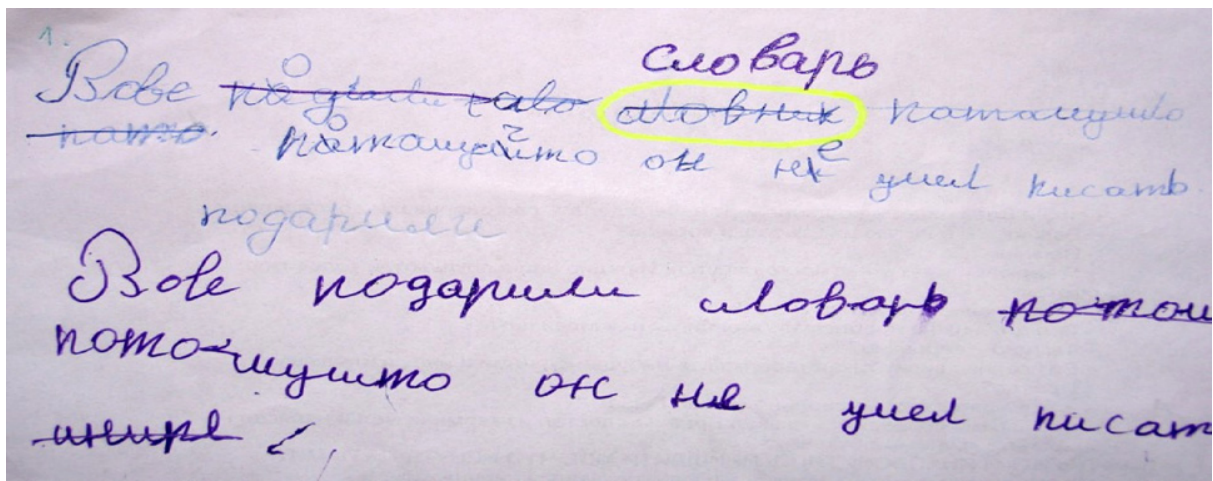

Fig. 1. Oleg's homework. 


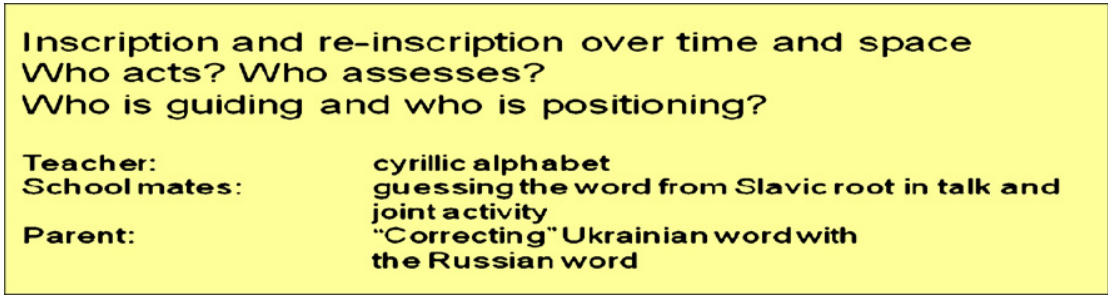

Fig. 2. Participants in inscription and re-inscription.

Table 2

Ukrainian vs. Russian suffixes.

\begin{tabular}{ll}
\hline 1. Слов- & $\mathbf{2}+\boldsymbol{\text { apb '-ar' }}$ \\
Slov-"word" & ("collection") \\
[Slavic root] & Russian suffix \\
& + ник '- nik' ("collection") \\
& Ukrainian suffix \\
\hline
\end{tabular}

share the same Slavic root слов-- (“word"). The Ukrainian “slovnik" and Russian "slovar"' use suffixes (-nik and -ar') which are identical in their semantic function, yet are formally different, as follows (Table 2):

This artifact can be interpreted at two levels: first, at the level of intersubjective space created by the immediate interaction between the mother and the boy and their understanding of the situation; and second, at the level of personal literacy histories of the participants and the way those influenced their momentary decisions. From the former perspective, Oleg and his mother had pursued the apparently common objective of producing a written text without mistakes. While they engaged in the process of writing, they had to negotiate their personal understanding of a mistake, their ways of correcting it, their idea of the final result, as well as the resources used for all the above purposes.

With these points of negotiation in mind, we realise that the boy and his mother had different agendas. In the first version of the sentence, Oleg was mainly concerned with (1) producing 'the correct' letter shapes and (2) producing a graphic representation which would directly correspond to the phonetic image of the text in his mind. His decisions had to do with choosing 'the correct' grapheme from the two writing systems available to him, thus seeking his mother's help whenever he failed to remember the letter shape in the Cyrillic system. At the same time, he relied on his own decoding abilities in order to arrive at a phonetically correct graphic representation. These decisions seemed to reveal the boy's claim for legitimacy in the community school as a social space: he felt he should present a formally correct and phonetically accurate representation in order to be accepted by his classmates and the teacher.

His mother's agenda, however, went beyond phonetic accuracy and appropriate graphemic choice. She wanted the text (1) to be free from mixing, i.e. written in one written code (Cyrillic) and one language (Russian), and (2) to correspond to orthography rules of that language. By striking out graphemes from the Roman-based alphabet as well as the Ukrainian word, she gave Oleg a lesson in language legitimacy and helped establish boundaries between written codes and languages. While Roman-based code was used in another school setting (the Portuguese school the boy goes to), it was not appropriate at the community setting. While Ukrainian was appropriate at home and with Ukrainian-speaking people; while some Ukrainian could be accepted in oral communication with the community school members, it was not acceptable in a written community school homework. Thus we saw the extent to which "(Re)production of [...] ideologies [...] is [...] interactionally accomplished” (Heller, 1996:8). By fixing the writer's identity (Kress, 2000), Oleg's mother warned Oleg of a flaw in the design of the newly created affinity space (Gee, 2004): a Ukrainian word could not possibly be used to construct an affinity space with Russian speakers.

The negotiations evident in the artefact production could be viewed the following way (Table 3).

\subsection{Personal trajectories: Oleg and his mother}

\subsubsection{Oleg}

When situated within the participants' personal histories of literacy learning, artifact and interaction receive another layer of interpretation. At the time of data collection, Oleg was an 8-year-old Ukrainian boy who had arrived to the country with his parents 2 years earlier. By the time he started attending Russian classes at the informal school, the boy had already been taught at his Portuguese school to read and write in Portuguese using a Roman-based alphabet. Besides, he had had some passive knowledge of Cyrillic alphabet because his grandmother used to read to him.

Ukrainian is the boy's native language. Unlike other Ukrainians in the class, who came from Eastern Ukraine's families and were Russian-speaking, the boy's Western Ukrainian family kept Ukrainian as a home language and in communication with their friends and acquaintances. Russian was nevertheless the language of communication among the students and parents of the community school. Sometimes Oleg would stumble upon a Russian word and would use a Ukrainian word instead. 
Table 3

Oleg and his mother.

\begin{tabular}{|c|c|c|}
\hline Oleg's mother actions & $\begin{array}{l}\text { Negotiations: performing uses } \\
\text { of languages at school }\end{array}$ & Oleg's actions \\
\hline $\begin{array}{l}\text { Points out rules constraining the relation between the } \\
\text { oral and written modes in Russian }\end{array}$ & Decoding practices (perception) & $\begin{array}{l}\text { Attempts to transduct from the oral into } \\
\text { written mode accurately, applying } \\
\text { available means }\end{array}$ \\
\hline $\begin{array}{l}\text { Restricts the choice of graphemes to those drawn from } \\
\text { Cyrillic-based Russian writing system }\end{array}$ & $\begin{array}{l}\text { Material artifacts, technologies, } \\
\text { writing systems (production) }\end{array}$ & $\begin{array}{l}\text { Attempts to produce graphic shapes from } \\
\text { available writing systems (Roman-based } \\
\text { and Cyrillic-based) }\end{array}$ \\
\hline \multicolumn{3}{|l|}{ Assesses the correctness of the graphic shapes } \\
\hline Restricts the choice of languages in school work & $\begin{array}{l}\text { Schooling practices } \\
\text { Languages of instruction }\end{array}$ & $\begin{array}{l}\text { Makes no distinction between Russian and } \\
\text { Ukrainian languages, having separated } \\
\text { them from Portuguese }\end{array}$ \\
\hline $\begin{array}{l}\text { Points out the boundaries between multilingual } \\
\text { and monolingual uses in oral vs. written } \\
\text { communication }\end{array}$ & Situated identities & $\begin{array}{l}\text { Manifests multiple and flexible identities } \\
\text { distributed across spaces of action }\end{array}$ \\
\hline
\end{tabular}

However, all Russian-speaking students and the teacher at the community school were generally able to deduce the meanings of the Ukrainian word either by the context of its use or by formal similarity to a Russian word.

Portuguese language has been present in Oleg's family life in Portugal in a range of activities and artifacts, starting from the Portuguese TV and conversations on the phone and with friends at home and in the street, to Portuguese homework, his favourite children books, notes from school, bills and street names, signs, etc. Besides, it permeated informal interaction between the students of the informal school during breaks.

\subsubsection{Oleg's mother}

Let us take a look at an extract from Oleg's mother interview:

“. . .My father was a pilot. ${ }^{5}$ Until my fourth grade our family had lived in the Far East, in Vladivostok. Ukrainian was not spoken in the family at all, even though both my mum and dad were Ukrainians. . . Then we went to live to Ukraine, to L'viv, ${ }^{6}$ and I got enrolled into a Ukrainian school. ${ }^{7}$ My cousin had taught me Ukrainian during the summer before the school. Very quickly, by the end of that year, I became the first student in Ukrainian in my class." (excerpt interview/19 Jan 2005, 13.20)

Oleg mother's story reflects the language policies in the Soviet Union at the time: the Russian language was the official language in Russian Federation and "the language of intercultural communication" across the USSR. It was also linked to social and professional promotion in the society; so families of different nationalities (not Russians) opted for speaking Russian at home. As a result, their children grew up without as much as passive knowledge of their native languages (e.g., in our study there were Byelorussians and Ukrainians with a limited knowledge of vocabulary items and no formal knowledge of their native languages' grammars). In the national republics (like Ukraine here) there were a number of national schools and Russian schools. Due to historical and cultural developments leading to a divide in the Ukrainian vs. Russian language use practices, Ukraine had a predominantly Ukrainian-speaking West and a Russian-speaking East.

Oleg's mother had to switch from one dominant language context into another, having to learn to speak and write a different language in a short period of time in order to be accepted as a rightful legitimate member of the community of learners within the particular school setting with its local configurations of practices and ideologies. She thus had to 'unlearn' Russian in order to be accepted within a Ukrainian learning context, that is, shed some part of her language identity along with associated cultural practices, adopting her resources to the new context.

\section{Discussion}

The data presented above described language use in different domains of social life and in different historical periods and geographical spaces - household dynamics in the 1990s London and school dynamics in central Portugal in the early 2000 s. Still, there was some scope for comparison, when we looked at the intersection of persons and their contexts affected by time, space and mobilities. We identified four factors that were constraining the scopes of action for the children involved. One, participants' perceptions of the resources in the events were configured by previous personal trajectories of socialisation in contexts. Two, the available material artifacts, technologies and resources, their trajectories through networks of practices and institutions afforded particular scopes of action but not others. Three, the events took place in particular settings and discursive spaces of social life, as well as the underlying rationalisations. Fourth, all these resources were negotiated in

\footnotetext{
5 Soviet Army air fighter.

6 Western Ukraine, where Ukrainian is predominant.

7 In Ukrainian schools, Ukrainian was the language of instruction and Russian was taught as a foreign language.
} 
discourse, in interaction and in semiotic activity. These four aspects implied personal assessments of the spaces of interaction, with consequences for the person's own engagement in future actions as well as for her perception of future senses of self. We end this discussion by outlining how we developed an understanding of the space and place of these interactions, their historical and structural configurations, but also the ways in which they created gaps for agency, creativity and mobility. Those are the tools that we aim to explore in future work. We now briefly expand on these aspects.

\subsection{Personal trajectories and persons in history}

A focus on the previous personal trajectories of socialisation in contexts and institutions - and the memories of this socialisation - made it evident that speakers found themselves in a hub of practices affecting their own perceptions of the available resources. They were influenced by institutional structures and historical migration flows, as these were experienced by Portuguese nationals in the UK and Russian and Ukrainian nationals in Portugal.

Since she was born in London and thus 2nd generation, Sónia's uses of language and literacy were conditioned by the multilingual distribution of Portuguese in the UK, affected by the length of settlement and the social profile of a more traditional migrant generation (as opposed to the more recent mobile and cosmopolitan generation affected by European citizenship). Sónia's exposure to Portuguese was thus associated to the distribution of language resources provided by the surrounding Portuguese institutions at the time and within this migrant space - the community association and the national diasporic identity discourses, yearly visits to Portugal, global media and - later on - the complementary school. At the time of this event, 8-year-old Sónia's exposure to literacy was mainly distributed by the English-based institutions where she spent most of her time, with very active personal investment. For instance, she displayed constant interest in history. This interest, however, seemed to have been brought on by her mother's own attention to history over the years, motivated by her relocated national sense of identity. There was thus a sense in which Sónia seemed to have expanded her mother's interest in 'history in Portuguese' into her own interest in 'history', enacted in her own multilingual practices, and situated in a London school environment which included access to the mainstream cosmopolitan cultural institutions.

The meeting of histories in person was particularly visible in Oleg's homework. Oleg had to deal with a number of authorities, displayed by different actors with distinct linguistic histories - here, the Russian community school teacher and the Ukrainian mother - within a dominant Portuguese society that only recognised these actors as 'vaguely Eastern European'. Just like his mother as a child back in Ukraine, Oleg also had to adopt a new meaning making resource, reconsider his design of semiotic space, and adjust his participation to the ways considered legitimate in the context. Oleg's literacy learning over the time of the research went from combining in the same word Portuguese and Russian written symbols, through using exclusively Russian printed and handwritten symbols, to separating handwritten and printed Russian symbols at a time. This gradual functional specialisation of literacy systems and registers is a result of socialisation in Portuguese and Russian dominant school settings, brought on by adult agents within the learning contexts in the intersection of their own learning trajectories. This allowed differing ways of assessing language and literacy - one, as it was enacted in Portuguese dominant formal school practices; two, in the Russian community school, including multilingual practices with his Russian teacher and his peers, and three, in intersubjective space with his Ukrainian mother.

\subsection{Material artifacts and resources}

Material artifacts, such as books and papers, writing systems, written homework texts, and textual displays in children's books were the outcomes of previous activities of inscription - reifications (cf. Barton and Hamilton, 2005, but also Kress, 2003 ) - situated in histories and institutions. They left traces and configured the scopes of action for the children in these events, well illustrated by Oleg's literacy learning trajectory. Their formal features-such as a traditional image-text display in Anita a Cavalo and the corresponding image-text movements around the page, or formal distinct links between sound and visual design in Russian and Ukranian - were the products of the cultural ways in which children's texts or orthographies in different linguistic systems had been inscribed in previous generations of print and script production and distribution. These included practices related to children's literature, to the production of grammars and to ways of 'doing school'. They were associated to collective memories, as well as to long-standing representations of the canon and the norm, situated in the cultural and national projects of Portugal, Russia and Ukraine. They evoked memories of schooling and literacy in the adult participants and affected the attitudes towards children's reading practices and linguistic ideologies, as well as the aspirations that these adults had for their children.

In these events, however, texts and orthographies interacted with others (The Big Book of Knowledge in Sónia's; the Roman alphabet and the Portuguese rules of orthography in Oleg's), which resulted in distinct repertoires and alignments displayed by children and adults. Sónia's active choice of books and Oleg's written strategy illustrated how these children actively deployed their multilingual resources with differentiated effects. Sónia had her way by bringing her own books and Englishbased interests into the event at home, as she disregarded her mother's attempts to impose a 'Livro da Anita Portuguese reading style'. Oleg's own creative multilingual writing strategy was constrained by his mother's corrections in a school task oriented to the informal Russian-speaking school, sustained by the adult's perceptions of legitimacy as strong separate boundaries between scripts and languages. This meant differentiated values for the languages involved, unequally distributed in the spaces of interaction. We will focus on these spaces in the next section. 
In short, the available material artifacts (e.g. books), technologies (e.g. writing systems) and resources (e.g. schooling practices, present and past), as well as their formal features (textual genres, links between visual design and linguistic representation, established 'doing school' practices) had followed particular trajectories through networks of practices and institutions. They afforded particular uses of language, of semiotic activity and of assessments by participants. They were the outcomes of previous inscriptions and socialisations in institutions, with differentiated symbolic capital.

\section{3. 'Doing home' and 'doing school'}

In the previous sections we illustrated how Sónia and Oleg acted in two discursive spaces of social life - "doing home' and “doing informal school'. 'Doing home' or “doing school' foregrounded different rationalisations (and modes of production of social life, cf. Santos, 1995, 2001) of what was relevant and irrelevant language activity in these spaces. In spite of the hybrid and polyphonic nature of discourse, 'doing home' tended to 'maximise' affective, leisure, familial and child-rearing discourses by negotiating what seemed to be important for children's survival in broader society, whereas 'doing school' 'maximised' discourses oriented to public life, citizenship or national affinity, situated in the institutional configurations of the broader Portuguese or British mainstream societies and the ways they dealt with global migrant flows of peoples and their languages. Sónia and her mother's individual actions at home displayed flexible multilingual uses, providing scope of negotiation for Sónia as they happened in the kind of informal interaction that promoted affective and children oriented discourses. This multilingual flexibility did not exist in the school task environment for Oleg in Portugal. In fact, the existence of more than one 'school' provided multiple schooling practices, mobilised by conflicting authorities, and sedimented in differently configured historical perceptions of language, language use and education. It implied co-existing, sometimes conflicting, guided reinventions of language and literacy in multiple institutional spaces, thus providing him with the perception of distinct ways with words for different educational practices.

Even though particular discursive rationalisations prevailed in different spaces, language use was polyphonic, prone to heterogeneity and sustained by contesting hegemonic discourses. In the next section, we briefly illustrate how we have seen this polyphony being discursively negotiated in semiotic activity.

\subsection{Discursive dynamics of re-scaling: focusing on recombination}

A focus on the use of language, literacy and discourse allowed us to observe the discursive dynamics happening in the process of recombining verbal, non-verbal and discursive material from contexts to contexts, in recontextualisation and rescaling (cf. Fairclough et al., 2004; Blommaert, 2005; Blommaert et al., 2005b; Collins et al., 2009). In Sónia's event, 'the use of Portuguese' was recombined in talk and non-verbal action: one code-switching move was recognised as 'translating skill' by her mother under the broader illustration of maintenance of Portuguese at home; the mother's traditional schooling voice was silenced by the child and framed by laughs; throughout the event, particular material artifacts were appropriated in detriment of others. These acts signalled discursive, material, verbal and non-verbal recombinations of resources that ended up voicing Sónia's multilingual use of Portuguese and English and silencing Dina's attempts to illustrate a non-existent monolingual use of Portuguese at home. Sónia's assessments on the multilingual use of language, as well as the choice of English in the last sequences set the dominant and prevailing key of the whole event. Finally, Oleg's homework decisions on spelling implied a recombination of links between graphemes and phonemes, writing systems and visual designs in the making, as these followed the ways in which he had been guided into his Russian learning. In it, the parent recognised the tension between the two affixes as the need to distinguish between literacy and language systems. Oleg found himself inbetween several authorities - Ukrainian, Russian and Portuguese dominant regimes of language and literacy - that allowed him to recognise different uses for different purposes and reflect on the appropriate use for the appropriate context. This was particularly clear in the way this child gradually displayed a clear distinction between Russian, Ukrainian and Portuguese literacy over the 18-month period of the study.

In short, resources were negotiated in interaction and in the semiotic activities of participants in the events in discursive re-scaling movements. First, participants anchored uses to different scales by performing recognised schooling voices, by establishing and imposing rules and boundaries between language regimes in different spaces or by mimicking discursive styles (being a consumer of TV programmes, being Portuguese). Second, participants resisted voices and value assessments by means of silences, interruptions and laughs, active choices of literacy materials that shifted the attention to selected ranges of discursive doings, as well as ongoing negotiations enacted in events and across contexts.

\subsection{Spaces, places and gaps: exploring scopes of action}

The four aspects mentioned above implied personal assessments about the spaces of interaction, with consequences for the person's own engagement in future actions and for the person's perception of future senses of self. We end this discussion by outlining how we developed an understanding of the space and place of these interactions, their historical and structural configurations, but also the ways in which they created gaps for agency, creativity and mobility. We started with insights about learning and individual agency, when we focused on Sónia and Oleg's creative moves. However, we needed an understanding of the ways these were conditioned by materials, institutions, the implied rationalisations and the respective legitimising discourses, also to assess the extent to which there was - or not - scope for negotiation beyond the personal dimension. 
Our understanding departed from an approach to structural place as "sedimented clusters of social relations acting in contemporary capitalist societies, as modes of producing forms of social agency, institutional forms, developmental dynamics, forms of exercising power, forms of law and forms of knowledge" (Santos, 1995:416-417; Santos, 2001:64). From the perspective of language and migration, however, sedimented clusters of social and power relations exist in semiotic and discursive negotiation determined by global dynamic flows, happening in the unique - and thus creative - historical configurations of language, persons, materials and contexts that might be viewed from other rationalities and thus distinct modes of production of social life. Alternative rationalities emerged precisely because of the polyphony of texts, artifacts and reifications, speakers, linguistic ideologies and discourses affected by mobility.

Even though permeated by mobilities and flows, moments and spaces of affinity were still influenced by sedimented regimes of language, literacy and semiotic action at the crossroads of complex systems. ${ }^{8}$ For this reason we investigated participants' past trajectories - imbued by institutional experiences - enacted in the local events under scrutiny. Our aim was to find first how these tensions were affecting the children's future aspirations. The combined focus on past trajectories and actual language and literacy activity allowed us to look further into the heterogeneity emerging from overlapping space/ time configuration, and to consider the polycentric speaking positions mentioned above. Further exploration on issues of space, confinement and heterotopia might allow us to incorporate a further layer of complexity into a dynamic and polycentric approach to the space of verbal interaction. ${ }^{9}$

\section{Concluding remarks}

In this paper we have made an attempt to analyse the ways in which, in our studies, Portuguese was acting both as a language of structure and a language of agency differently distributed in two multilingual repertoires in Europe. We have looked at the uses of this language in distribution with other languages (English, Russian and Ukrainian ) by first focusing on the creative semiotic activity of individuals in dialogue with their contexts. We thus focused on (a) how the person acted creatively in situated events; (b) how this creativity was affected by the social, institutional and historical conditions of the contexts of use; (c) how a look at the past trajectories of texts, artifacts and reifications, speakers, linguistic ideologies and discourses have given us tools to explore participants' scopes of action and possibilities for the future. The intersection of all these aspects allowed us to explore the existence of polycentric speaking positions for the speakers involved in the events, i.e., a number of other possible utterances situated in a meeting of histories from which the person acted and made linguistic decisions in creative ways.

As we gradually focused on the conditions of contexts, we needed an understanding of the space and place of these interactions, their historical and structural configurations, but also the ways in which they created gaps for agency, creativity and mobility. Alternative juxtaposing rationalities emerged precisely because of the mobility of texts, artifacts and reifications, speakers, linguistic ideologies and discourses. For this reason, an exploration on scales of time and space and on some discursive dynamics of recontextualisation and re-scaling was instrumental in our analysis - it allowed us to (a) look simultaneously at how broader scales of social action, with juxtaposing temporalities and spatialities, were in co-habitation (and eventual competition) in local events; and (b) explore moments of resistance and agency in interaction and discourse, as instances that indicated this juxtaposition.

Below, we identify some of the perspectives that are influencing our work:

1. Social cultural approaches to learning and identity, in particular activity theory, were useful in understanding negotiations of language and literacy as meetings of histories happening in discursive activity (Engeström, 1999; Lave and Wenger, 1991; Lemke, 2000; Rogoff, 1990; Rogoff et al., 2002; Wenger, 1998).

2. Life histories and biographies were seen as ways of contextualising processes and ways with words. A focus on history in person (Holland and Lave, 2001) was useful to explain assessments situated in subjectivities that were affecting personal action. The use of this historical approach allowed us to identify conflicting narratives interacting within the same event.

3. A linguistic ethnographic approach to language and literacy helped us understand how 'languages' and multilingual repertoires were being interactionally and discursively accomplished in the field (Creese, 2008; Heller, 1996).

4. A critical interpretive framework prompted us to consider the moves of language, literacy and material resources through scales of space and time. This helps us understand how discursive negotiations affect the symbolic capital of actual verbal

\footnotetext{
${ }^{8}$ We are exploring agency by looking at creative semiotic movements acting in "lines of flight" in-between structures and hegemonic uses of language, cf. Deleuze and Guattari (1987). However we want to acknowledge that there are sedimented modes of production of social life being permeated by contesting historical assessments brought on by mobility and migration. Acts are both situated in momentary and long durational regimes of use. The links explored by Chouliaraki and Fairclough (1999), as well as by Rampton (2006), on the intersections and junctures of tradition and modernity and modernity-and-late modernity (Rampton, 2006:19), were important to explore in our perspective. However, we need to complement an understanding of our contexts with approaches to modernity that take into account local knowledges, from theoretical standpoints that develop thinking from other non-dominant rationalities. Yet, the work by these particular authors provide a standpoint that assumes issues of power, domination and inequality yet "take seriously the message of critical postmodernism" ... without... "losing the possibility of social science" (cf. the 'neo-modernist' perspective, cf. Comaroff and Comaroff, 1992:45, cited in Rampton, 2006:36). We want to assume a position that pushes this debate further, also to reflect on the development on the modern/ postmodern and epistemological debates in Portuguese speaking contexts, and on the ways these debates might improve further social, language and discursive research in contexts where Portuguese plays some kind of dominant, nondominant, or historical role.

${ }^{9}$ Cf. the concept of heterotopia by Foucault (1984). For space, polycentricity and multilingualism, cf. Blommaert (2005), Blommaert et al. (2005a,b), among others.
} 
exchanges (cf. Barton, 1994; Barton and Hamilton, 2005; Blommaert, 2005, 2007; Blommaert et al., 2005b; Collins et al., 2009; Chouliaraki and Fairclough, 1999; Heller and Martin-Jones, 2001; Jones, 2000; Rampton, 2006).

Our focus lay on issues of personal agency and creativity, but we now turn to the broader issues of context and citizenship embedded in personal experience. Both sites were - and are - going through fast changing processes of transformation in the public space, affecting the ways in which individuals assess their scope of action, and envisage public participation. In the first site, there is growing visibility of mobile European Portuguese nationals in English-dominant London and the UK in general, illustrated in the recent interest and the emerging literature about this group in Britain in recent years. Besides, the use of Portuguese spreads through various different diasporic movements in need of systematic research in postcolonial European (as well as non-European) contexts. In the second site, there is evident presence of the Eastern European migrant community in a Portuguese-speaking host society, at odds with the need to integrate immigrants into its social texture. The concept of Portugal as a multilingual society is being forged and negotiated in public discourses as we speak. It thus should be urgently documented and analysed in a critical way. By optimizing the position offered by the diasporic and intermediate experience of Portugal and Portuguese at the European scale, the ultimate aim of this paper lies in the need to find languages of description that might help us understand and explain the contribution of multilingual uses and representations to discern the complex configurations of time and space acting in personal, social and institutional life.

\section{Acknowledgements}

We acknowledge the Centre for Social Studies, the School of Arts and Humanities of the University of Coimbra, Portugal, the Calouste Gulbenkian Foundation and Fundação para a Ciência e Tecnologia, Portugal for institutional and financial support throughout the time of the two research projects (Clara Keating, various grants; Olga Solovova - MA and PhD grants, respectively).

\section{References}

Abreu S Guida, Elbers, Ed, 2005. Introduction: the social mediation of learning in multiethnic schools. European Journal of Psychology of Education XX, 3-11. Abreu, Guida, Lambert, Hannah C., 2003. The Education of Portuguese Students in England and the Channel Islands Schools. Final Report. Department of Psychology, University of Luton.

Ançã, Maria Helena (Ed.), 2007. Aproximações à Língua Portuguesa. Centro de Investigação Didáctica e Tecnologia na Formação de Formadores, Universidade de Aveiro.

Baganha, Maria Ioannis, 1988. Social marginalization, government policies and emigrants' remittances: Portugal 1870-1930. Estudos e Ensaios 431-449. Baganha, Maria Ioannis, 2001. A cada Sul o seu Norte: Dinâmicas migratórias em Portugal. In: Santos, B. (Ed.), Globalização: Fatalidade ou Utopia. A Sociedade Portuguesa Perante os Desafios da Globalização, vol. 1. Editora Afrontamento, Porto, pp. 135-159.

Baganha, Maria Ioannis, 2005. Política de imigração: A regulação dos fluxos. Revista Crítica de Ciências Sociais 73, $29-44$.

Barradas, Olga, 2000. Now you see them, now you don't: Portuguese students, social inclusion and academic attainment. Goldsmith's Journal of Education 3 (1), 2-13.

Barradas, Olga, 2010a. Linking community language and mainstream schools: a case for Portuguese language and culture classes. In: Martin, P., Lytra, V. (Eds.), Multilingual Spaces: Complementary Schools in Contemporary Britain. Multilingual Matters, London, pp. 135-149.

Barradas, Olga, 2010b. Multilingual spaces: complementary schools in contemporary Britain. In: Martin, Lytra, (Eds.), Sites of Multilingualism. Multilingual Matters, London.

Barton, David, 1994. Literacy. An Introduction to the Ecology of Written Language. Blackwell, Oxford.

Barton, David, Hamilton, Mary, 2005. Literacy, reification and the dynamics of social interaction. In: Barton, D., Tusting, K. (Eds.), Beyond Communities of Practice. Cambridge University Press, London, pp. 14-35.

Blommaert, Jan, 2005. Discourse. A Critical Introduction. Cambridge University Press, London.

Blommaert, Jan, 2007. Sociolinguistic scales. Intercultural Pragmatics 4-1, 1-19.

Blommaert, Jan, Collins, James, Slembrouck, Stef, 2005a. Polycentricity and interactional regimes in 'global neighborhoods'. Ethnography 6 (2), 205235.

Blommaert, Jan, Collins, James, Slembrouck, Stef, 2005b. Spaces of multilingualism. Language and Communication 25 (3), $197-216$.

Cardoso, João N. Correia, 2004. Sociolinguística Urbana. O Português Falado e Escrito no Reino Unido. Unpublished doctoral dissertation. University of Coimbra, Portugal.

Chouliaraki, Lillie, Fairclough, Norman, 1999. Discourse in Late Modernity: Rethinking Critical Discourse Analysis. Edinburgh University Press, Edinburgh.

Collins, J., Slembrouck, S., Baynham, M., 2009. Globalization and Language in Contact: Scales, Migration and Communicative Practices. Advances in Sociolinguistics Series. Continuum, London.

Creese, Angela, 2008. Linguistic ethnography. In: King, K.A., Hornberger, N.H. (Eds.), Encyclopedia of Language and Education, 2nd Edition, Volume 10: Research Methods in Language and Education. Springer Science and Business Media LLC, New York, pp. $229-241$.

Deleuze, Giles, Guattari, Felix, 1987. A Thousand Plateaux: Capitalism and Schizofrenia (transl. by Brian Massumi) University of Minnesota Press, Minneapolis, MN.

Dionízio, Sandra (Ed.), 2005. Português Língua não Materna. Instituto de Estudos Sociais e Económicos, Lisboa.

Engeström, Yrjö, 1999. Activity theory and individual and social transformation. In: Engeström, Y., Miettinen, R., Punamaki, R.L. (Eds.), Perspectives on Activity Theory. Cambridge University Press, London, pp. 19-38.

Fairclough, Norman, Jessop, Robert, Sayer, Andrew, 2004. Critical realism and semiosis. In: Joseph, J., Roberts, J. (Eds.), Realism, Discourse and Deconstruction. Routledge, London, pp. 23-42.

Foucault, Michel, 1984. Dits et écrits 1984. Des espaces autres (conférence au Cercle d'études architecturales, 14 mars 1967). Architecture, Mouvement, Continuité 5, 46-49.

Gee, James Paul, 2004. Situated Language and Learning: A Critique of Traditional Schooling. Routledge, London.

Heller, Monica, 1996. Legitimate language in a multilingual school. In: Martin-Jones, M., Heller, M. (Eds.), Education in Multilingual Settings: Discourse, Identities and Power. Linguistics and Education, vol. 8 (2). pp. 139-157.

Heller, Monica, Martin-Jones, Marilyn, 2001. Voices of Authority: Education and Linguistic Difference. Comparative Studies in Linguistics and Education, 1. Ablex, London.

Holland, Dorothy, Lave, Jean, 2001. History in Person: Enduring Struggles, Contentious Practice, Intimate Identities. School of American Research Press, Santa Fe, New Mexico. 
Jones, Kathryn, 2000. Texts, mediation and social relations in a bureaucratized world. In: Martin-Jones, M., Jones, K. (Eds.), Multilingual Literacies: Reading and Writing Different Worlds. John Benjamins, Amsterdam, pp. 209-228.

Keating, Maria Clara, 2001. Routes through Literacy. The Lived Experiences with Literacy of Portuguese Women in London. Unpublished Ph.D. manuscript. Linguistics Department, University of Lancaster, England.

Keating, Maria Clara, 2005. The person in the doing: negotiating the experience of self. In: Barton, D., Tusting, K. (Eds.), Beyond Communities of Practice. Cambridge University Press, London, pp. 105-138.

Keating, Maria Clara, 2009. Changing participation in changing practice: uses of language and literacy among Portuguese migrants in the UK. In: Baynham, M., Collins, J., Slembrouck, S. (Eds.), Globalization and Language Contact: Spatiotemporal Scales, Migration Flows and Communicative Practices. Continuum Press, London.

Kress, Gunther, 2000. Early Spelling. Between Convention and Creativity. Routledge, London.

Kress, Gunther, 2003. Literacy in the New Media Age. Routledge, London.

Lave, Jean, Wenger, Etienne, 1991. Situated Learning: Legitimate Peripheral Participation. Cambridge University Press, London.

Lemke, Jay L., 2000. Across the scales of time. Artifacts, activities, and meanings in ecosocial systems. Mind, Culture and Activity 7 (4), 273-290.

Martin-Jones, Marilyn, Santarrita, Paula, 1990. The Portuguese speech community. In: Edwards, V., Alladina, S. (Eds.), Multilingualism in the British Isles. Longman, London, pp. 228-240.

Mateus, Helena M., 2002. Uma Política de Língua para o Português. Edições Colibri, Lisboa.

Mateus, Helena M., Fischer, Gloria, Pereira, Dulce (Eds.), 2005. Diversidade Linguística na Escola Portuguesa. DGIDC, Ministry of Education, Lisbon.

Norton, Bonnie, 2000. Identity and Language Learning: Gender, Ethnicity and Educational Change. Longman, London.

Pereira, Dulce, 2006. Crescer Bilingue. Publicações ACIME, Lisboa.

Rampton, Ben, 2006. Language in Late Modernity. Interaction in an Urban School. Cambridge University Press, London.

Reid, Euan, Smith, Greg, Morawska, Anna, 1985. Languages in London. Community Languages and Education Project. Institute of Education, University of London.

Rogoff, Barbara, 1990. Apprenticeship in Thinking. Cognitive Development in Social Context. Oxford University Press, Oxford

Rogoff, Barbara, Goodman Turkanis, Carolyn, Bartlett, Leslee, 2002. Learning Together: Children and Adults in a School Community. Oxford University Press, Oxford.

Santos, Boaventura S., 1995. Toward a New Common Sense: Law, Science and Politics in the Paradigmatic Transition. Routledge, London.

Santos, Boaventura S., 2001. Os processos da globalização. In: Santos, B.S. (Ed.), Globalização: Fatalidade ou Utopia: A Sociedade Portuguesa Perante os Desafios da Globalização, vol. 1. Editora Afrontamento, Porto.

Solovova, Olga, 2005. Literacy Practices among children of Eastern European immigrants in Portugal. Unpublished manuscript, MA dissertation. Faculdade de Letras, Universidade de Coimbra, Portugal.

Stubbs, Michael (Ed.), 1985. The Other Languages of Britain. Linguistics Minority Project. Routledge and Kegan Paul, London.

Wenger, Etienne, 1998. Communities of Practice: Learning, Meaning and Identity. Cambridge University Press, London.

Zentella, Ana Celia, 2007. US-Mexico border crossers: polycentric identities and conflicting constructions of bilingualism. In: Conference Paper at the Centre for Social Studies, School of Economics of the University of Coimbra, 19 September, p. 2007.

Clara Keating is Researcher at the Centre for Social Studies and teaches at the School of Arts and Humanities, University of Coimbra, Portugal. She explores links between identity, discourse, literacy and learning in Portuguese-based migrant settings, from a linguistic ethnographic perspective. Publications include "The person in the doing: negotiating the experience of self”. In: Barton and Tusting (Eds.), Beyond Communities of Practice, CUP, 2005 and “Changing participation in changing practice: uses of language and literacy among Portuguese-based migrant contexts". In: Collins, J., Baynham, M., and Slembrouck, S. (Eds.) Globalization and Language Contact, Continuum, 2009.

Olga Solovova is a doctoral student at the School of Arts and Humanities and a researcher at the Centre for Social Studies, University of Coimbra, Portugal. She develops a Portuguese state funded research (FCT scholarship) on multilingual communicative practices by Eastern European school children within the broader social process of integration of immigrants in Portuguese society. Publications include a critical review of Kalaja et al. (2008) Narratives of Learning and Teaching EFL, Palgrave Macmillan in Applied Linguistics Journal, 2009, Oxford University Press; A new stereotype in the making: Imigrantes de Leste in the Press. In: Barker, A.D. (Ed.) The Power and Persistence of Stereotyping, 2005. University of Aveiro; Progressive markers in the creoles of Cabo Verde and Guiné-Bissau: the outcome of different sociolinguistic histories. In: Fernandez, M., et al. (Eds.) Los criollos de base ibérica. ACBLPE, 2003. 